\title{
Effect of Phase Change Material Eutectic Plates on the Electric Consumption of a Designed Refrigeration System
}

\author{
Rachid Djeffal ${ }^{1,2}$, Sidi Mohammed El Amine Bekkouche ${ }^{1 *}$, Mustapha Samai ${ }^{2}$, Zohir Younsi ${ }^{3,4}$, Redouane Mihoub ${ }^{1}$, \\ Abdelaziz Benkhelifa ${ }^{1}$ \\ ${ }^{1}$ Unité de Recherche Appliquée en Energies Renouvelables, URAER, Centre de Développement des Energies Renouvelables, \\ CDER, 47133, Ghardaïa, Algeria \\ ${ }^{2}$ Groupe de Thermique, Département d'Architecture, Institut d'Architecture et des Sciences de la Terre, Université Ferhat \\ Abbas, Sétif 19000, Algérie \\ ${ }^{3}$ FUPL, Hautes Etudes d'Ingénieur (HEI), LGCgE (EA 4515), Rue de Toul, F-59000 Lille, France \\ ${ }^{4}$ Univ. Artois, Laboratoire Génie Civil \& Geo-Environnement LGCgE- EA 4515, Technoparc Futura, F-62400 Béthune, \\ France
}

Corresponding Author Email: smabekkouche@gmail.com

https://doi.org/10.18280/i2m.190101

Received: 8 November 2019

Accepted: 3 January 2020

\section{Keywords:}

refrigeration system, phase change material $P C M$, energy saving, over-consumption of energy, energy consumption, thermal stratification, melting temperature

\begin{abstract}
The main objective of this research is to design an improved refrigeration system incorporating a phase change material; experimental measurements have been carried out to reduce energy consumption. The adopted method was based on the comparison of two cases: the first corresponded to a classical cell and the second concerned an isolated experimental cell with phase change material (PCM) eutectic plates. An energy saving of up to $12.88 \%$ has been recorded. In the event of leaks, the operation will subsequently generate an over-consumption which was estimated at $22.03 \%$ compared to the initial consumption and $42.16 \%$ for a cell combined with eutectic plates. An incorrect choice of the thermostat temperature leads to unnecessary and expensive energy consumption. These materials have helped us to limit and sometimes almost avoid the stratification of temperature; on average, the temperature stratification was $0.68^{\circ} \mathrm{C}$ per $23 \mathrm{~cm}$. A better air circulation from the evaporator can be promoted with a correct food distribution; it is possible, therefore, to reduce significantly the over-consumption due to cooling/freezing of the food. For a programmable thermostat $\left(-10^{\circ} \mathrm{C}\right)$, a light over-consumption that can reach only $1.69 \%$ for bread and about $0.40 \%$ for water has been achieved.
\end{abstract}

\section{INTRODUCTION}

As depicted in the literature [1], thermal energy storage systems are used particularly in buildings and in industrial processes. Latent heat storage is a thermal storage solution that operates the latent heat of a phase change material. The phase change energy will be absorbed during the phase change material melting process and will then be restored during its solidification. This solution requires the use of a heat transfer fluid to transfer heat from the source to the storage unit [2]. The energy density of phase change materials $\left(\mathrm{kWh} / \mathrm{m}^{3}\right)$ is higher than that of sensible heat storage systems, which results a greater compactness and lower thermal losses of latent heat storage systems. The stored heat depends upon the mass and latent heat of the phase change material fusion [3]. In fact, convenient use of phase change materials in refrigerator applications is one of the most active research areas for latent heat storage with higher efficiency.

Several researchers have conducted investigations on phase change material applications to improve the performance of domestic refrigerators. Nyoman Suamir et al. [4] have shown that the water-based mixtures containing $5 \%$ to $35 \%$ of cornoil ester have freezing temperatures between -3.5 and $-27^{\circ} \mathrm{C}$. Other researchers [5] have revealed that judicious uses of phase change materials in vapor compression refrigeration systems have promoted great effects on the system performance, compressor on-off cycle and saving in electrical energy. Earlier works have included reports on the performance influences of the phase change temperature and phase change material thickness. The strengths and weaknesses of using phase change material in the evaporator, condenser, compartment section and compressor were analyzed descriptively, and compared with practical findings. Moreover, a novel refrigeration system using an available phase change material was developed to reduce energy consumption and test experimentally their performance [6]. In recent years, the most energy and economically efficient refrigeration system is that of solar absorption [7]. Nevertheless, in order to evaluate the energy efficiency of a refrigerator, two eutectic phase change materials in a cascade arrangement have been tested. This experiment employed technique to reduce the temperature of the condenser surface during the refrigeration cycle and consequently improve the coefficient of performance (COP) [8]. Rasta et al. [9] have been able to develop a water based phase change material for cold thermal energy storage that constitutes mixtures of water with small amount vegetable oil addition. An addition of 5\% to $10 \%$ in water solution could decrease the freezing temperature from $0^{\circ} \mathrm{C}$ down to respectively $-3.5^{\circ} \mathrm{C}$ to $-6.5^{\circ} \mathrm{C}$. Furthermore, it was noted that the power consumption can be 
reduced by using the phase change materials in various locations in household refrigerators [10,11]. Extra works on an innovative water phase change material heat exchanger for cooling [12] and on phase transitions within heat exchangers, and phase change material storage tank [13] have been carried out to develop a comprehensive numerical model and empirical correlations, respectively. Schalbart et al. [14] have been proven the great potential of phase change materials to preserve the food quality while appropriately managing their operating energy; energy savings in the order of $8-20 \%$ have been reported. This type of material can also be combined with refrigerator trucks; this technology promotes low energy consumption with less greenhouse gas emissions. With an interior temperature which is approximately $-18^{\circ} \mathrm{C}$, a phase change material of a latent heat of $154.4 \mathrm{~kJ} \mathrm{~kg}^{-1}$ and a melting temperature of $-26.7^{\circ} \mathrm{C}$ was required [15]. Therefore, as part of the retained result in some contributions [16], the description of the technical process and its sequences during the (partial or complete) charging/discharging cycle justify relevant aspects allowing the release (storage) of the previously stored (released) cold energy. On the other hand, mathematical modeling of phase change material heat exchanger applied to domestic refrigerators is feasible based on the available literature approaches. This is what has been done in works published by Bakhshipour et al. [17] where they have separately modeled the different refrigeration cycles using phase change materials. Assumptions of the entire system are carried out for each part separately, including compressor, evaporator, expansion valve, condenser and phase change material heat exchanger. Other researchers have announced that latent heat storage using paraffin as phase change material will predict an increase of the cycle's refrigeration capacity by about $30 \%$ during the discharging cycle [18]. Finally, through above-mentioned [19], it has been shown that there is no satisfactory description of the constrained melting process, the problem of heat transfer during the phase change process is the most important one. These are among the reasons why authors herein have addressed the recommendations, which can be handled it for future work in this field.

The objective of this research work is to develop an experimental device consist of a refrigeration cycle machine that offer wide possibilities (freezing and cooling of products in a reduce time). Accordingly, it is connected to adjustment accessories (electrical control box, temperature thermostat, control valves, wattmeter, thermometers...etc.) and an automatic electronic counter to evaluate the corresponding power consumption. A phase change material with a melting temperature of $-5^{\circ} \mathrm{C}$ has been incorporated into this refrigeration system to reduce the electrical energy consumption. The adopted approaches which are based on two different cases: the first corresponds to the case of a classical cell and the second concerns an isolated experimental cell with phase change material eutectic plates.

This work was structured around several parts; after the introduction, an overall description of the experimental refrigeration system was provided. Experiment and significant results have been reported in section 3. Several items were dealt with the power consumption of the refrigerating machine, energy over-consumption due to the technical breakdown, incorrect choice of the thermostat temperature, and homogeneity and air thermal stratification inside the experimental cell. Finally, the last section was dedicated to the conclusion of the research work.

\section{DESCRIPTION OF THE EXPERIMENTAL REFRIGERATION SYSTEM}

The mounting of this device of multifunctional type was based on the refrigeration cycle described in Figure 1. The entire system is consisting of several compartments including compressor (Figure 2), evaporator, expansion valve and condenser. The experimental prototype is made in the form of a refrigerating/freezing cell integrated with a phase change material (Figure 3).

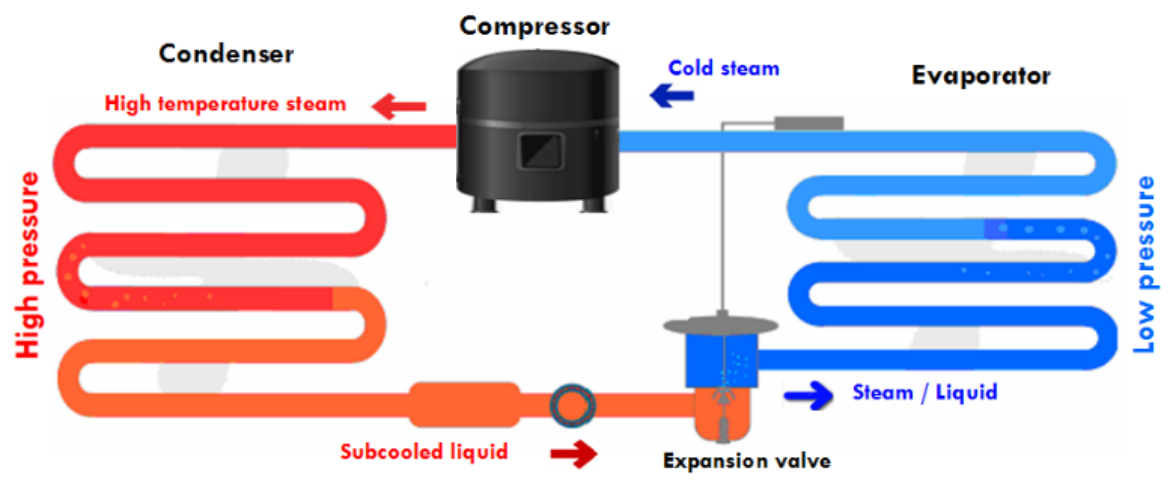

Figure 1. Descriptive scheme of the refrigeration n cycle
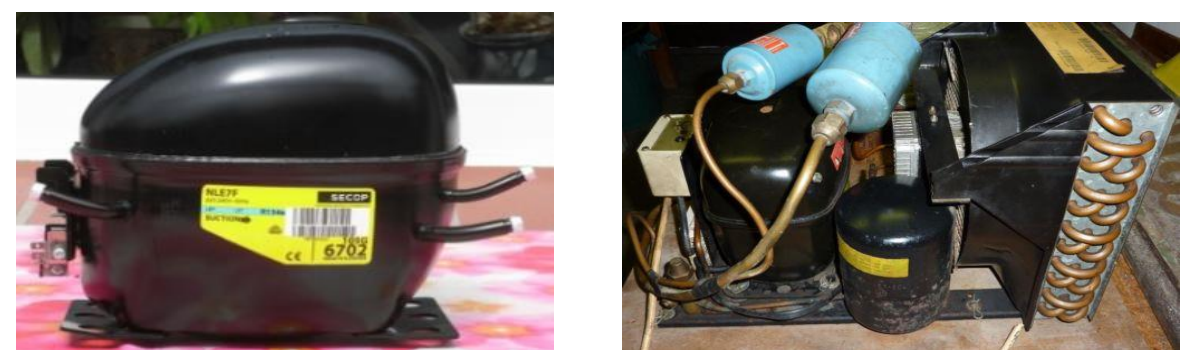

Figure 2. Danfoss SC15BXT2 compressor installation 


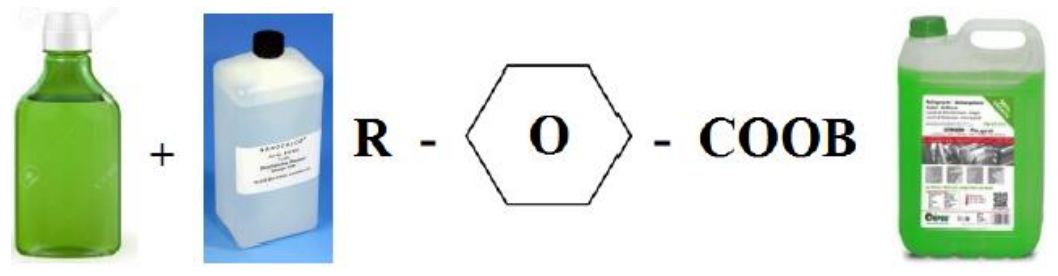

Figure 3. Phase change material preparation process, $18 \%$ alcohol $+82 \%$ distilled water, $\mathrm{T}_{\mathrm{f}}=-5^{\circ} \mathrm{C}$

\subsection{Danfoss SC15BXT2 compressor}

Mechanical energy expended by the compressor allows the gas to be sucked in at low pressure and low temperature, to compress it, then to repress it to the condenser under high pressure and high temperature. So it circulates to cool the inside of the cell. The role here is to suck the vapours produced by vaporizing the refrigerant in the evaporator at a low pressure under the operating conditions, then discharge these compressed vapours to the condenser at high pressure to allow their condensation by cooling [20].

\subsection{Condenser}

The condenser is a heat exchanger which allows the transition from the gaseous to the liquid state. The gas passes through the condenser and gradually transforms into liquid by exchange with air circulating around the condenser area. This is the first state change due to condensation. It should be noted that the condenser yields its energy to air. Then the liquid passes through the dehydrator, which filters out any impurities and traps the moisture.

\subsection{Expansion valve}

The liquid reaches the expander which allows its partial vaporization by abrupt reduction in pressure. The expansion valve is a calibrated orifice to the installation power. This component is a passive part of the refrigeration circuit and essential to perform the compression/detente cycle allowing the transfer of calories or frigories from the evaporator to the condenser. The fluid expansion is an isenthalpic detente in which the amount of total heat contained in the liquid upstream of the expansion valve and in the liquid/vapour mixture downstream of the orifice has not changed.

There was only an energy transfer a change in the physical state of the fluid. The role of the expander is to modify the equilibrium conditions of the liquid refrigerant leaving the condenser by lowering the fluid temperature. Its role is to control the liquid filling of the evaporator when it is with variable aperture [20].

\subsection{Evaporator}

The liquid arrives at the evaporator which allows the passage from the liquid to the gaseous state. Gradually the liquid turns into gas by the contact of air circulating around the evaporator; this is the second state change (evaporation). Note that the evaporator absorbs energy in the considered medium, whether it is air or water. Then the vapours return to the compressor for a new cycle.

Evaporators are heat exchangers and sources of cold production. They ensure the passage of the heat flux from the medium to be cooled to the refrigerant. This heat flux has as effect the vaporization of the liquid refrigerant contained inside the evaporator. The absorption of this flux at constant temperature will be by releasing its latent heat of vaporization. Some works have represented an update of previous studies on their parametric evaluation efficiency [21].

\subsection{Refrigeration / freezing cell}

The refrigeration system also consists of an experimental refrigeration/freezing cell of parallelepiped shape $(54 \mathrm{~cm}$ long, $47 \mathrm{~cm}$ wide and $56 \mathrm{~cm}$ high) equipped with all necessary adjustment accessories (valves, wattmeter, thermometers...etc). This cell is an isolated enclosure, linked to the various cold production components. Its location allows checking both the proper functioning of the condenser and the evaporator, by stopping, starting the refrigeration system, and performing supply voltage and nominal intensity measurements during the fan operation. External and internal coatings are made of aluminium sheet.

Rapid cooling and freezing cells are characterized by evaporators with very high air flow. The rapid freezing of 400 $\mathrm{kg}$ of mashed potatoes in $400 \mathrm{~g}$ trays requires a cooling power of $45 \mathrm{~kW}$ for an evaporation temperature of $-40^{\circ} \mathrm{C}$, and an air flow of $60000 \mathrm{~m}^{3} / \mathrm{h}$. As an indication, the electrical powers implemented in the mechanical cells vary from 50 to $70 \mathrm{~W}$ per $\mathrm{kg}$ of nominal load. For example, a rapid cooling cell with a nominal capacity of $70 \mathrm{~kg}$ has a power of 3 to $4 \mathrm{~kW}$ (including fan). The electrical consumption of a cell during the cooling cycle varies from 90 to $60 \mathrm{Wh}$ per $\mathrm{kg}$ of the feed, depending on the cell importance and their type, how it is charged, the thickness and the type of the food to be cooled [22].

For fast freezing cells, the electrical powers implemented in the mechanical cells are substantially the same as those of the fast cooling cells, but the consumptions are high estimated at around three times more. They range from 180 to $270 \mathrm{Wh}$ per $\mathrm{kg}$ of feed, depending on the cell importance and their type, how it is charged, the thickness and the type of the food to be cooled [22].

\subsection{Phase change material plates}

Experiments were carried out to the characteristics of the melting / solidification of a phase change material at a melting temperature of $-5^{\circ} \mathrm{C}$. This has been prepared within our research unit using a melting tester thermometer and mixing distilled water and alcohol. It contains $18 \%$ alcohol and $82 \%$ distilled water. The resulting boiling temperature is $102^{\circ} \mathrm{C}$. This preparation has spread under conditions of dominant asepsis.

The experimental device is a refrigeration cycle machine allowing a wide range of applications. It is connected to adjustment accessories (electrical control box, temperature thermostat, valves, wattmeter, thermometers...etc.) and to an electric energy counter with high precision (Figure 4). 


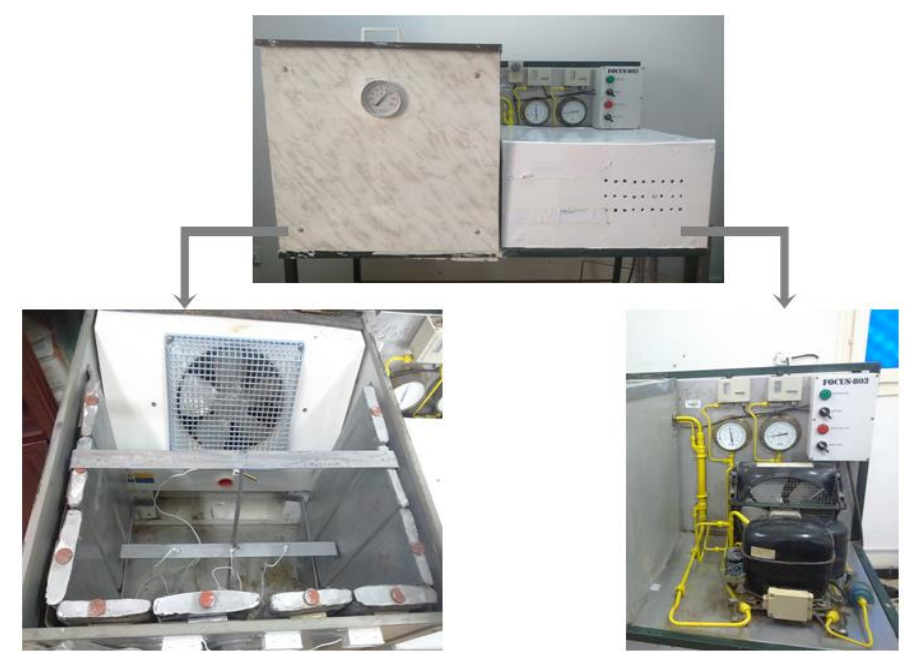

Figure 4. Global descriptive images of the developed prototype

\section{EXPERIMENT AND SIGNIFICANT RESULTS}

To test this prototype, we will let it run for not less than 3 days in order to find possible failures. The deployed method will be based on two distinct situations: in the first, a conventional experimental enclosure was used, the second concerns an isolated experimental enclosure (polystyrene) with phase change material plates integrated on its inner side. At first, the machine is switched off; the initial temperature is close to the temperature of the outside ambient air. After switching on, it is possible to plot up to 6 different curves on Figure 5 knowing that the thermostat has been set to $-7.5^{\circ} \mathrm{C}$. The electrical consumption of the machine, in kilowatt hours, is a function of the entire on-mode duration. Predicted results will be established from the measured values to investigate the phase change material effect of hot water demand. For the first case, after 30 hours, it was noted that the thermostat has not been triggered, and therefore generates a high electrical consumption due to ice accumulation on one part of the refrigeration circuit. This situation is assumed to be due to leaking seals (our present case), a faulty condenser or/and motor fan or a poor "cold control" thermostat. As a solution, it appears more appropriate to intelligently integrate an electrical resistance to melt the accumulated ice balls in parallel. For the second case, approximately 40 hours were required to see an ice layer on one part of the refrigeration system (Figure 6).

Reducing energy costs is an important part of energy management. It is within this context that obtained results have been dissected. The energy saving was calculated by integrating phase change material eutectic plates and considering that this machine runs without any failure during its start-up (Figure 7). Assuming this perfect refrigeration machine can be operated year round; results have led to a reduction in energy of up to $12.88 \%$.

For the same quantity of the stored energy, latent heat storage requires less volume than sensible heat storage because the latent heat is much higher than the calorific capacity. It is therefore absolutely logical to find that the energy consumption of the refrigeration system during the first process phases is high in the case of a refrigeration system with phase change material eutectic plates. The required energy supplied by the electric power (generation) supply system allowed (at the same time) the phase change material to store latent heat and cool the air inside the cell. The duration requested ( $9 \mathrm{~h}: 37 \mathrm{mn}$ ), which allowed us to have an energy saving and the delay raised in this respect are therefore justified by the process as detailed above.

Layers of ice can then form and will accumulate quickly on the indicated part of the circuit when the blackout occurred. This phenomenon generates a marked increase in power consumption compared to the displayed values under nonfault conditions. The growing demand for energy is highly sensitive especially for a phase change material cell (Figure 8). These results seem very logical for a phase change material enclosure, since the consumption under normal operating conditions displays lowest values.
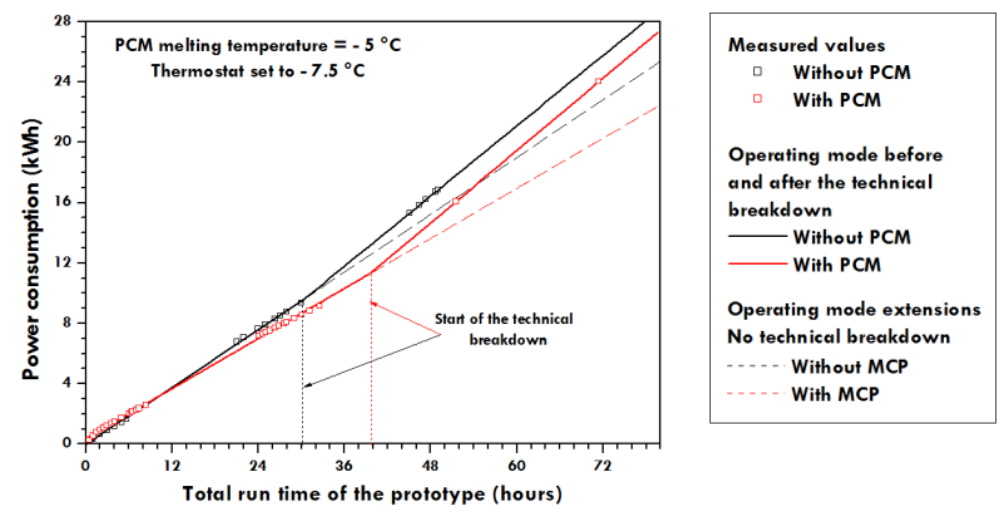

Figure 5. Calculation and prediction of the power consumption of the refrigerating machine, case of an experimental cell filled with water bottles $\left(\mathrm{T}_{\text {Thermostat }}=-7.5^{\circ} \mathrm{C}\right)$ 


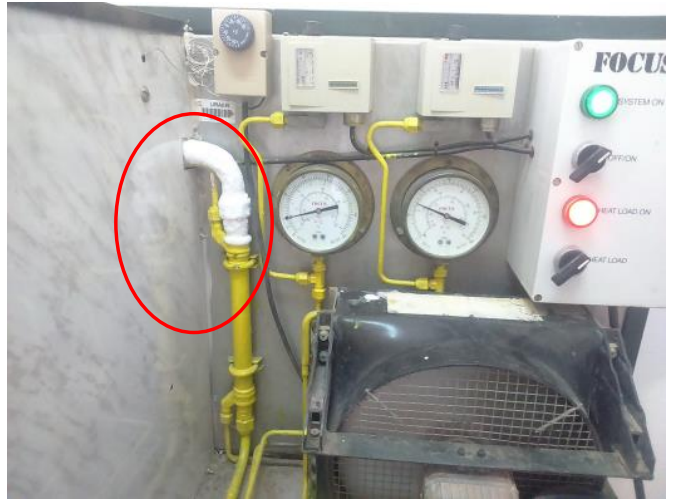

Figure 6. Illustrative picture, indicating the amount of the accumulated ice on one part of the refrigeration circuit
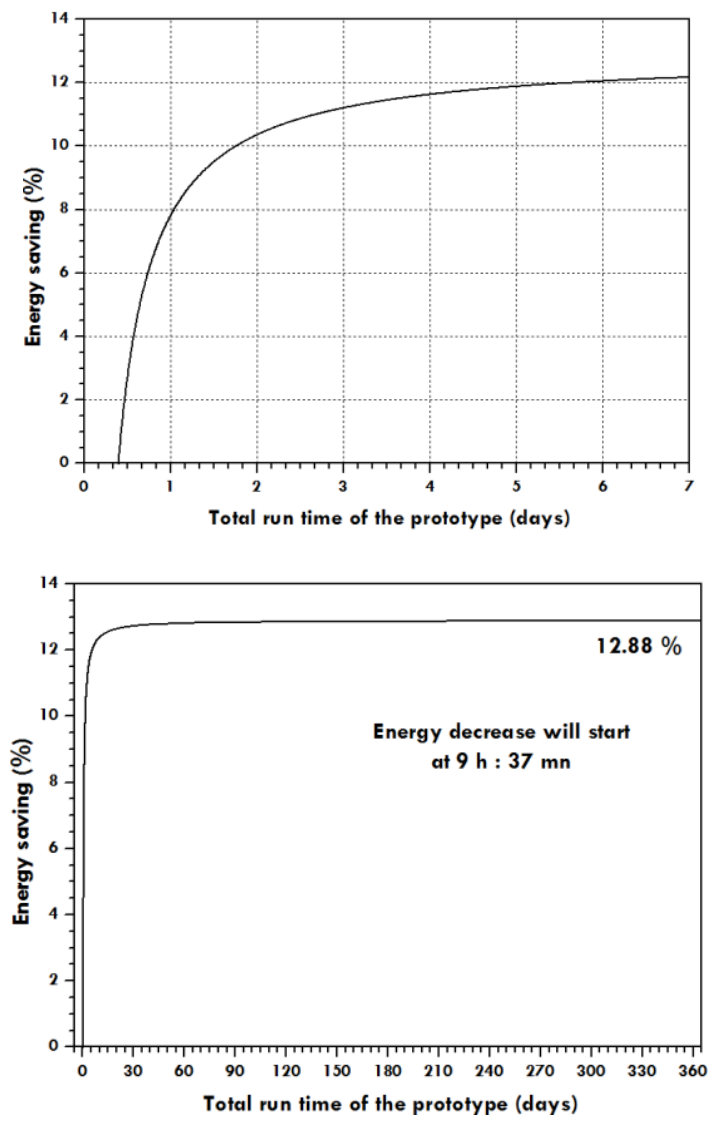

Figure 7. Energy saving in the designed refrigeration system with latent heat storage

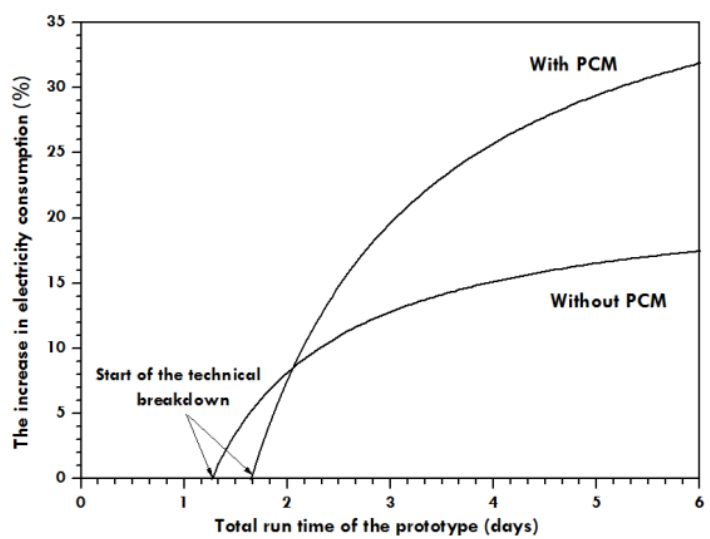

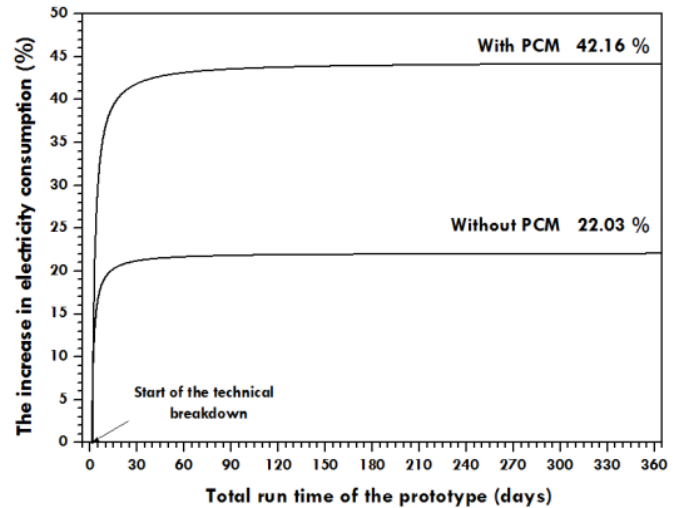

Figure 8. Over-consumption of energy of the refrigerating machine due to the technical breakdown $\left(\mathrm{T}_{\text {Thermostat }}=-7.5^{\circ} \mathrm{C}\right)$

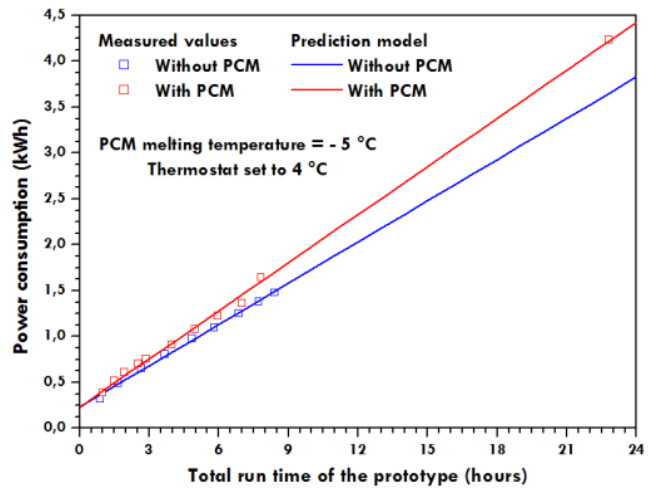

Figure 9. Calculation of the total energy use of the refrigerating machine, case of an experimental cell filled with water bottles $\left(\mathrm{T}_{\text {Thermostat }}=4^{\circ} \mathrm{C}\right)$
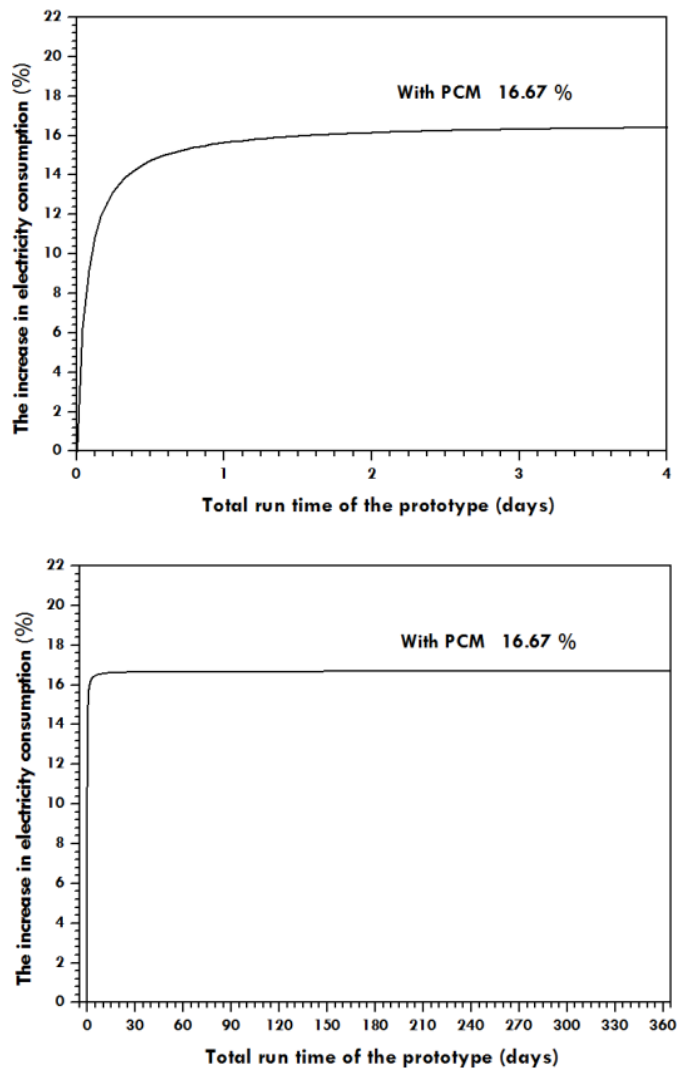

Figure 10. Over-consumption of energy of the refrigerating machine due to the incorrect choice of the thermostat temperature $\left(\mathrm{T}_{\text {Thermostat }}=4^{\circ} \mathrm{C}\right)$ 
However, it is very important to note that an incorrect choice of the thermostat temperature leads to unnecessary and expensive energy consumption. According to the example shown in Figures 9 and 10, a thermostat set at $4^{\circ} \mathrm{C}$ can result in an over-consumption of more than $16 \%$.

Phase change materials can change the physical state over a temperature range; their reactivity is based on a simple physical principle. At surrounding temperatures of around phase change material melting temperature, this used phase change material starts to change its phase from liquid to solid by crystallizing and absorbing energy by latent heat transfer. Thus, phase change materials will become liquid by restoring the stored energy when the environment temperature increases. If the thermostat is set at 4 degrees, there will never be a change in the phase change material physical state since it is very far from the melting temperature $\left(-5^{\circ} \mathrm{C}\right)$.

The air temperature is not always homogeneous but can increase with height. This phenomenon is referred to as temperature stratification, hot air tends to rise and cool air tends to sink. A study conducted by Ouarhlent et al. [23] was dealing with the numerical simulation of natural convection in a shaped cavity. They are interested in the heat and mass transfer induced by natural convection. If the flow regime is dominated by the natural convection process, thermal stratification can be established. But it can be partially or totally eliminated by an intensive flow current. This phenomenon therefore depends on the thermal state, the height of the enclosed space and the air movement in the space to be cooled. In order to identify it, experiment requires a precise and well-conducted approach. Three type-K thermocouples inserted along the vertical meridian axis (56 cm high) at different heights: $5 \mathrm{~cm}, 28 \mathrm{~cm}$ and $51 \mathrm{~cm}$ and an AGILENT acquisition unit connected to a PC were used to collect temperature data. Nevertheless, Table 1 can give an idea about the air stratification inside the experimental cell. A comparison between the different profiles was made for a thermostat temperature of $-10^{\circ} \mathrm{C}$.

Experimentally, thermal stratification is defined as the difference between maximum and minimum temperature. In our case, in the operating mode and according to Table 1, it is most remarkable between the cell center and at $51 \mathrm{~cm}$ height. The summarised values show that phase change materials are helping us to limit and sometimes almost avoid the stratification of temperature. With this air supply type and without phase change material, the maximum temperature stratification was around $12.17^{\circ} \mathrm{C}$ per meter of height equivalent to $2.8^{\circ} \mathrm{C}$ per $23 \mathrm{~cm}$. In addition, based on average values, the temperature stratification was found to be about $5.44^{\circ} \mathrm{C}$ per meter of height equivalent to $1.25^{\circ} \mathrm{C}$ per $23 \mathrm{~cm}$. Moreover, by integrating phase change material eutectic plates, the maximum stratification of the air temperature was reduced; it was around $5.2174{ }^{\circ} \mathrm{C}$ per meter of height $\left(1.2^{\circ} \mathrm{C}\right.$ per $\left.23 \mathrm{~cm}\right)$. On average, the temperature stratification in this case was $2.94^{\circ} \mathrm{C}$ per meter of height equivalent to $0.68^{\circ} \mathrm{C}$ per $23 \mathrm{~cm}$. The evaporator air has therefore been intensively mixed, ensuring good temperature homogeneity and better stratification.

Table 1. Instantaneous temperatures within the experimental cell as a function of the vertical height $\left(\mathrm{T}_{\text {Thermostat }}=-10^{\circ} \mathrm{C}\right)$

\begin{tabular}{|c|c|c|c|c|c|c|}
\hline \multirow{2}{*}{$\begin{array}{l}\text { Time } \\
(\mathbf{m n})\end{array}$} & \multicolumn{3}{|c|}{$\begin{array}{c}\text { Without phase change material \& Height of } \\
\text { measurement points }\left({ }^{\circ} \mathrm{C}\right)\end{array}$} & \multicolumn{3}{|c|}{$\begin{array}{c}\text { With phase change material \& Height of } \\
\text { measurement points }\left({ }^{\circ} \mathrm{C}\right)\end{array}$} \\
\hline & $5 \mathrm{~cm}$ & $\begin{array}{c}28 \mathrm{~cm} \\
\text { in the cell center }\end{array}$ & $51 \mathrm{~cm}$ & $5 \mathrm{~cm}$ & $\begin{array}{c}28 \mathrm{~cm} \\
\text { in the cell center }\end{array}$ & $51 \mathrm{~cm}$ \\
\hline 0 & 20.2 & 20 & 20.3 & 20.1 & 19.9 & 20.2 \\
\hline 30 & 5.4 & 5.1 & 5.7 & 4.2 & 3.8 & 4.7 \\
\hline 60 & 0 & 0 & 0.3 & -1.2 & -1.5 & -0.9 \\
\hline 90 & -4.8 & -5.1 & -4.2 & -9.7 & -10 & -9 \\
\hline 120 & -7.1 & -8.3 & -6.5 & -8.9 & -9.2 & -8.5 \\
\hline 150 & -5 & -7.5 & -4.7 & -9.9 & -10 & -9.8 \\
\hline 180 & -9.1 & -9.7 & -8.5 & -8.9 & -9.2 & -8.5 \\
\hline 210 & -6.2 & -7.7 & -5.3 & -9.8 & -10 & -9.7 \\
\hline 240 & -9.2 & -9.9 & -8.5 & -9.4 & -9.7 & -9.1 \\
\hline 270 & -6.1 & -7.6 & -5.2 & -8.7 & -9.2 & -8.2 \\
\hline 300 & -8.9 & -9.3 & -8.3 & -9.6 & -10 & -9.2 \\
\hline 330 & -9.5 & -10 & -9.1 & -8.9 & -9.5 & -8.3 \\
\hline 360 & -9.1 & -9.7 & -8.3 & -9.2 & -9.6 & -8.7 \\
\hline 390 & -9.5 & -9.9 & -9.1 & -9.9 & -10 & -9.7 \\
\hline 420 & -6.5 & -8.3 & -6.1 & -9.4 & -9.8 & -9.1 \\
\hline 450 & -9.4 & -9.9 & -8.9 & -9.7 & -10 & -9.3 \\
\hline 480 & -5.7 & -7.6 & -5.2 & -9.5 & -9.8 & -9.2 \\
\hline 510 & -9.3 & -9.9 & -8.7 & -9.3 & -9.5 & -8.9 \\
\hline 540 & -9.9 & -10 & -9.7 & -8.7 & -9.1 & -8.2 \\
\hline 570 & -6.7 & -7.2 & -6.1 & -9.9 & -10 & -9.9 \\
\hline 610 & -7.9 & -8.4 & -7.7 & -8.8 & -9.2 & -8.3 \\
\hline 640 & -9.3 & -9.8 & -8.9 & -9.4 & -9.9 & -8.9 \\
\hline 670 & -6.1 & -7.4 & -5.6 & -8.9 & -9.4 & -8.6 \\
\hline 700 & -9.2 & -9.7 & -8.9 & -8.7 & -9.1 & -8.5 \\
\hline 720 & -9.3 & -9.8 & -9.1 & -8.7 & -9.1 & -8.6 \\
\hline
\end{tabular}


Table 2. The influence of the food product on the cumulative electrical power $(\mathrm{kWh}), \mathrm{T}_{\text {Thermostat }}=-10^{\circ} \mathrm{C}$

\begin{tabular}{cccccccccccc}
\hline Time (min) & 20 & 26 & 30 & 45 & 60 & 90 & 120 & 150 & 180 & 210 & 240 \\
\hline Vacuum cell & 0.2 & 0.244 & 0.275 & 0.392 & 0.497 & 0.711 & 0.78 & 0,85 & 1,05 & 1,09 & 1,36 \\
10 bread baguettes & 0,21 & 0,261 & 0,281 & 0,401 & 0,509 & 0,723 & 0,81 & 0,88 & 1,08 & 1,13 & 1,39 \\
10 liters of water & 0,21 & 0,257 & 0,279 & 0,398 & 0,499 & 0,72 & 0,8 & 0,87 & 1,08 & 1,12 & 1,38 \\
\hline
\end{tabular}

Using this same application (freezing for $\mathrm{T}_{\text {Thermostat }}=-10^{\circ} \mathrm{C}$ ), it is possible to superficially test the influence of the food on the electrical consumption. The measurements operating conditions are the same for the three cases: vacuum freezing, freezing of 10 bread baguettes (the occupied equivalent volume was $6.90 \%$ compared to the cell volume), and freezing of 10 liters of water (the equivalent volume was $7.04 \%$ compared to the cell volume). The cumulative electrical power corresponding to the different freezing processes are presented in Table 2.

It will be remembered that the temperature of the food product is proportional to the electrical consumption required to cool it. By ensuring a correct food distribution while avoiding overloading the cell, a better air circulation (air exchange) from the evaporator can be promoted. In these conditions, the refrigeration system will result in overconsumption estimated at $3.33 \%$ for bread baguettes and $2.45 \%$ for water. It is considerable in the early stages; it can exceed $6.97 \%$ for bread baguettes and $5.33 \%$ by freezing water. But, within a few moments (up to 30 minutes), the average over-consumption in electrical energy will decrease and then be fixed around $2.74 \%$ for bread and about $1.85 \%$ for water. As a result, with a good flow of air (from the evaporator) inside the test cell, it is possible to reduce significantly the over-consumption due to cooling/freezing of the food. For a programmable thermostat $\left(-10^{\circ} \mathrm{C}\right.$ for example), it is possible to achieve a light over-consumption that can reach only $1.69 \%$ for bread and about $0.40 \%$ for water.

\section{CONCLUSION}

In this research work, an experimental prototype consisting of a refrigeration cycle machine offering wide possibilities (freezing and cooling of products in a reduced time) was developed. A control panel has been implemented on the machine to manually choose cooling or freezing. A phase change material with a melting temperature of $-5^{\circ} \mathrm{C}$ has been incorporated into this refrigeration system to reduce the electrical energy consumption. However, it has been shown that significant energy savings have been achieved through latent transfers. These processes are currently conceivable making it possible to reduce the volume of an energy storage element (compactness), or even to greatly increase the amount of the contained energy in the same storage volume (energy density).

As results, integrating phase change materials into the cell envelope can reduce the energy consumed by up to $12.88 \%$. A technical breakdown or a tightness failure will cause a marked increase in energy consumption; it is estimated at $22.03 \%$ for an ordinary case and $42.16 \%$ for a cell combined with phase change material eutectic plates. The growing demand for energy is highly sensitive especially for a phase change material cell. These results are logical since the consumption under normal operating conditions displays lowest values. As a solution, it appears more appropriate to intelligently integrate an electrical resistance to melt the accumulated ice balls in parallel. Otherwise, an incorrect choice of the thermostat temperature leads to unnecessary and expensive energy consumption, a thermostat set at $4{ }^{\circ} \mathrm{C}$ can result in an overconsumption of more than $16 \%$.

Its main applications in the socio-economic sector are listed as follows:

- Freezing and cooling of products in a reduced time: the rapid lowering of food temperature maintains their unaltered moisture content and prevents the normal growth of bacteria

- Homogenization and temperature regulation inside the enclosure

- Extending the shelf-life of food products in the case of an electric supply failure

- Delaying certain technical breakdowns due to sealing faults (such as ice accumulation)

\section{REFERENCES}

[1] Sarbu, I., Sebarchievici, C. (2018). A comprehensive review of thermal energy storage. Sustainability 2018 , 10(1): 191. http://dx.doi.org/10.3390/su10010191

[2] Pielichowsk, K., Pielichowski, K. (2014). Phase change materials for thermal energy storage. Progress in Materials $\quad$ Science, $65:$ 67-123. http://dx.doi.org/10.1016/j.pmatsci.2014.03.005

[3] Nazir, H., Batool, M., Osorio, F.J.B., Isaza-Ruiz, M., Xu, X., Vignarooban, K., Phelan, P., Inamuddin, Kannan, A.M. (2019) Recent developments in phase change materials for energy storage applications: A review. International Journal of Heat and Mass Transfer, 129: 491-523.

https://doi.org/10.1016/j.ijheatmasstransfer.2018.09.126

[4] Nyoman Suamir, I., Made Rasta, I., Sudirman, Tsamos, K.M. (2019). Development of corn-oil ester and water mixture phase change materials for food refrigeration applications. Energy Procedia, 161: 198-206. https://doi.org/10.1016/j.egypro.2019.02.082

[5] Bista, S., Hosseini, S.E., Owens, E., Phillips, G. (2018). Performance improvement and energy consumption reduction in refrigeration systems using phase change material (PCM). Applied Thermal Engineering, 142: 723-735. https://doi.org/10.1016/j.applthermaleng.2018.07.068

[6] Chen, X., Zhang, Q., Zhai, Z.J., Wu, D., Liao, S. (2017). Experimental study on operation characteristics of a novel refrigeration system using phase change material. Energy and Buildings, 150: 516-526. http://dx.doi.org/10.1016/j.enbuild.2017.05.069

[7] Khan, M.M.A., Saidur, R., Al-Sulaimana, F.A. (2017). A review for phase change materials (PCMs) in solar absorption refrigeration systems. Renewable and Sustainable Energy Reviews, 76: 105-137. http://dx.doi.org/10.1016/j.rser.2017.03.070

[8] Pirvaram, A., Sadrameli, S.M., Abdolmaleki, L. (2019). Energy management of a household refrigerator using 
eutectic environmental friendly PCMs in a cascaded condition. $\quad$ Energy, 181: 321-330. https://doi.org/10.1016/j.energy.2019.05.129

[9] Rasta, I.M., Suamir, I.N. (2018). The role of vegetable oil in water based phase change materials for medium temperature refrigeration. Journal of Energy Storage, 15: 368-378. https://doi.org/10.1016/j.est.2017.12.014

[10] Vadhera, J., Sura, A., Nandan, G., Dwivedi, G. (2018). Study of phase change materials and its domestic application. Materials Today: Proceedings, 5(2): 34113417. https://doi.org/10.1016/j.matpr.2017.11.586

[11] Joybari, M.M., Haghighat, F., Moffat, J., Sra, P. (2015). Heat and cold storage using phase change materials in domestic refrigeration systems: The state-of-the-art review. Energy and Buildings, 106: 111-124. http://dx.doi.org/10.1016/j.enbuild.2015.06.016

[12] Roccamena, L., El Mankibi, M., Stathopoulos, N. (2019). Development and validation of the numerical model of an innovative PCM based thermal storage system. Journal of Energy Storage, 24: 100740. https://doi.org/10.1016/j.est.2019.04.014

[13] Wu, J., Tremeac, B., Terrier, M.F., Charni, M., Gagnière, E., Couenne, F., Hamroun, B., Jallut, C. (2016). Experimental investigation of the dynamic behavior of a large-scale refrigeration - PCM energy storage system, validation of a complete model. Energy, 116(Part 1): 3242. http://dx.doi.org/10.1016/j.energy.2016.09.098

[14] Schalbart, P., Leducq, D., Alvarez, G. (2015). Ice-cream storage energy efficiency with model predictive control of a refrigeration system coupled to a PCM tank. International Journal of Refrigeration, 52: 140-150. http://dx.doi.org/10.1016/j.ijrefrig.2014.08.001

[15] Liu, M., Saman, W., Bruno, F. (2012). Development of a novel refrigeration system for refrigerated trucks incorporating phase change material. Applied Energy, 92:
336-342.

http://dx.doi.org/10.1016/j.apenergy.2011.10.015

[16] Bejarano, G., Vargas, M., Ortega, M.G., Castaño, F., Normey-Rico, J.E. (2018). Efficient simulation strategy for PCM-based cold-energy storage systems. Applied Thermal Engineering, 139: 419-431. https://doi.org/10.1016/j.applthermaleng.2018.05.008

[17] Bakhshipour, S., Valipour, M.S., Pahamli, Y. (2017). Parametric analysis of domestic refrigerators using PCM heat exchanger. International Journal of Refrigeration, 83: 1-13. https://doi.org/10.1016/j.ijrefrig.2017.07.014

[18] Korth, T., Loistl, F., Storch, A., Schex, R., Krönauer, A., Schweigler, C. (2020). Capacity enhancement of air conditioning systems by direct integration of a latent heat storage unit. Applied Thermal Engineering, 167: 114727. https://doi.org/10.1016/j.applthermaleng.2019.114727

[19] Kenisarin, M.M., Mahkamov, K., Costa, S.C., Makhkamova, I. (2020). Melting and solidification of PCMs inside a spherical capsule: A critical review. Journal of Energy Storage, 27: 101082. https://doi.org/10.1016/j.est.2019.101082

[20] Papin, P.J., Jacquard, P. (1996). Installation Frigorifique. Volume $2,7^{\text {th }}$ edition.

[21] https://energieplus-lesite.be/techniques/froidalimentaire7/cellules-de-refroidissement-et-decongelation-rapides/, accessed on Feb. 9, 2020.

[22] Cucumo, M.A., Ferraro, V., Galloro, A., Gullo, D., Kaliakatsos, D., Nicoletti, F. (2019). Parametric CFD analysis for the evaluation of evaporative cooler performances. Instrumentation Mesure Métrologie, 18(5): 427-434. https://doi.org/10.18280/i2m.180501

[23] Ouarhlent, F., Soudani, A. (2019) Numerical study of thermal convection in a porous medium. Instrumentation Mesure $\quad$ Métrologie, 18(1): 69-74. https://doi.org/10.18280/i2m.180111 